\title{
Out-Of-Plane Bending Stiffnesses in Offshore Mooring Chain Links Based on Conventional and Advanced Numerical Simulation Techniques
}

\author{
Joonmo Choung, Jae-bin Lee $\oslash^{*}$ and Young Hun Kim ${ }^{* *}$ \\ "Department of Naval Architecture and Ocean Engineering, Inha University, Incheon, Korea \\ "Department of Naval Architecture and Ocean System Engineering, Kyungnam University, Changwon, Korea \\ 기존/개선 수치 해석 기법을 이용한 계류 체인 링크의 면외 굽힘 강성 \\ 정준모 \\ "인하대학교 조선해양공학과 \\ "경남대학교 조선해양시스템공학과
}

KEY WORDS: Out-of-plane bending moment 면외 굽힘 모멘트, Tension load 인장력, Interlink angle 인터링크 각, Tension angle 인장각, Hotspot stress 국부 응력, 3-link analysis 3-링크 해석, Multi-link analysis 다중-링크 해석

\begin{abstract}
After an accident involving mooring link failures in an offloading buoy, verification of the fatigue safety in terms of the out-of-plane bending (OPB) and in-plane bending (IPB) moments has become a key engineering item in the design of various floating offshore units. The mooring links for an $8 \mathrm{MW}$ floating offshore wind turbine were selected for this study. To identify the OPB stiffness (OPB moment versus interlink angle), a numerical simulation model, called the 3-link model, is usually composed of three successive chain links closest to the fairlead or chain hawse. This paper introduces two numerical simulation techniques for the 3-link analyses. The conventional and advanced approaches are both based on the prescribed rotation approach (PRA) and direct tension approach (DTA). Comparisons of the nominal stress distributions, OPB stiffnesses, hotspot stress curves, and stress concentration curves are presented. The multiple link analyses used to identify the tension angle versus interlink angle require the $O P B$ stiffness data from the 3-link analyses. A convergence study was conducted to determine the minimum number of links for a multi-link analysis. It was proven that 10 links were sufficient for the multi-link analysis. The tension angle versus interlink angle relations are presented based on multi-link analyses with 10 links. It was found that the subsequent results varied significantly according to the 3-link analysis techniques.
\end{abstract}

\section{1. 서 론}

서아프리카에 설치된 Girassol 원유 하역 플랫폼의 계류 체인 손상 사고 이후에 여러 연구 활동을 통하여 OPB(Out-of-planebending) 모멘트가 계류 체인의 파손 원인임이 밝혀졌다(Jean et al., 2005; Melis et al., 2005; Rampi and Vargas, 2006).

Lim et al.(2010) 및 $\mathrm{Kim}$ and $\mathrm{Kim}(2017)$ 은 링크 간의 마찰 계 수, 검사 하중의 크기, 인장력의 크기, 링크의 공칭 지름, 그리 고 링크 소재가 $\mathrm{OPB}$ 강성에 미치는 영향을 조사하였다. 2006년 부터 2013년까지 SBM Offshore는 소위 "Chain out of plane bending" JIP(Joint industry project)를 통하여 다양한 OPB 관련 연구 결과를 제시하였다(Rampi et al., 2016a; Rampi et al., 2016b). 이 JIP를 통하여 다양한 실험적 연구 및 수치 해석 연구
가 수행되었다. 이들은 실제 스케일 계류 체인 링크에 대한 피 로 실험을 수행하여 면외 굽힘 피로를 평가하였다. 또한 실험 모델에 대한 유한 요소 해석을 수행하였다. 프랑스 선급은 JIP 연구 결과를 바탕으로 $\mathrm{OPB}$ 강성을 추정할 수 있는 경험식을 제 시하였다(BV, 2014).

$\mathrm{OPB}$ 강성을 수치 해석을 통하여 도출하기 위해서 통상 3 개 링크로 구성된 모델이 이용된다. 이를 본 연구에서는 3-링크 해 석으로 명명한다. 앞에서 언급된 선행 연구들은 3-링크 해석 중 에서 $\mathrm{OPB}$ 모멘트를 강제로 유발시키기 위하여 강제 변위 (Prescribed rotation)를 적용하였다. 강제 변위에 기반한 3-링크 해석법은 연속 조건을 만족하도록 첫번째 링크를 적절히 고정 한 후, 세번째 링크에 인장력과 강제 변위를 순차적으로 부여하 는 방법이다. 본 연구에서는 이러한 3-링크 해석법을 PRA

Received 13 June 2018, revised 18 September 2018, accepted 18 October 2018

Corresponding author Jae-bin Lee: +82-032-860-7346, beeny06@gmail.com ORCID: http://orcid.org/0000-0002-7224-0770

(c) 2018, The Korean Society of Ocean Engineers

This is an open access article distributed under the terms of the creative commons attribution non-commercial license (http://creativecommons.org/licenses/by-nc/3.0) which permits unrestricted non-commercial use, distribution, and reproduction in any medium, provided the original work is properly cited. 
(Prescribed rotation approach)라 명명한다.

반면, 3번째 링크에 OPB 인장각(Tension angle)을 가지는 인장 력(Tension load)을 직접 부여하는 기법이 새로이 제시되었다 (Choung and Han, 2016a; Choung and Han, 2016b; Choung and Lee, 2018). 본 연구에서는 이러한 3-링크 해석법을 DTA(Direct tension approach)라 명명한다. 그들은 DTA가 PRA보다 현실적인 $\mathrm{OPB}$ 모멘트와 응력을 유발할 수 있는 방법이라고 주장하였다.

3-링크 해석법에 따라 국부 응력(Hotspot stress)과 인터링크 각(interlink angle)의 관계는 심각한 영향을 받을 수 있다. 뿐만 아니라 3-링크 해석에서 얻은 $\mathrm{OPB}$ 강성(OPB 모멘트와 인터링 크 각(Interlink angle)의 관계)은 $\mathrm{OPB}$ 인장각과 인터링크 각의 관계를 규명하기 위한 다중-링크 해석법(Multi-link analysis)의 입력 데이터로 사용된다. 따라서 3-링크 해석 결과가 후행 결과 에 미치는 영향은 매우 심각하다.

본 연구에서는 $8 \mathrm{MW}$ 급 부유식 해상 풍력 발전기 $(\mathrm{Li}$ et al., 2018)에 공칭 지름 $107 \mathrm{~mm}$ 계류 링크가 사용되었을 경우를 가 정하여 벤치마크 해석을 수행할 것이다. 두가지 3-링크 해석법 (PRA 및 DTA)에 따른 링크 중앙부의 응력 상태를 비교할 것이 다. 또한 PRA, DTA, BV 가이드라인(BV, 2014)에 따른 $\mathrm{OPB}$ 강 성, 국부 응력, 그리고 응력 집중 계수를 비교할 것이다. 다중링크 해석에 적합한 링크의 개수를 찾기 위한 수렴도 해석이 진행될 것이다. 3-링크 해석에서 얻은 $\mathrm{OPB}$ 강성을 다중-링크 해 석에 적용하여 인장각-인터링크 각을 제시할 것이다.

\section{OPB 발생 기구 및 피로 해석 절차}

\subsection{OPB 모멘트 발생 기구}

해양 플랫폼에 적용되는 모든 계류 링크는 생산 단계에서 검 사 하중(Proof load) 테스트를 거친다. 검사 하중은 최소 파단 하 중(Minimum breaking load, MBL)의 $70 \%$ 를 적용한다(DNV, 2010). 이와 같이 높은 검사 하중으로 인하여 계류 체인 링크 사이의 접촉면에 소성 변형이 발생하여 링크끼리 접촉 면적이 넓어진 다. 넓어진 접촉 면적은 설치 후 운용 단계에서 $\mathrm{OPB}$ 모멘트를 유발하는 원인이 된다. 위 언급한 과정을 Fig. 1에 보인 바와 같 이 4단계로 분류할 수 있다. 이는 검사 하중 단계(Proof load step), 검사 제하 단계(Proof unload step), 인장력 단계(Tension load step), OPB 모멘트 단계(OPB moment step)이다.

$\mathrm{OPB}$ 발생 기구를 설명하기 위하여 3개의 링크를 Fig. 2에 도 식화하였다. 링크 \#1은 선체에 가장 가까운 링크이며, 페어리드 (Fairlead) 또는 체인 호스(Chain hawse)에 의하여 완전히 구속되

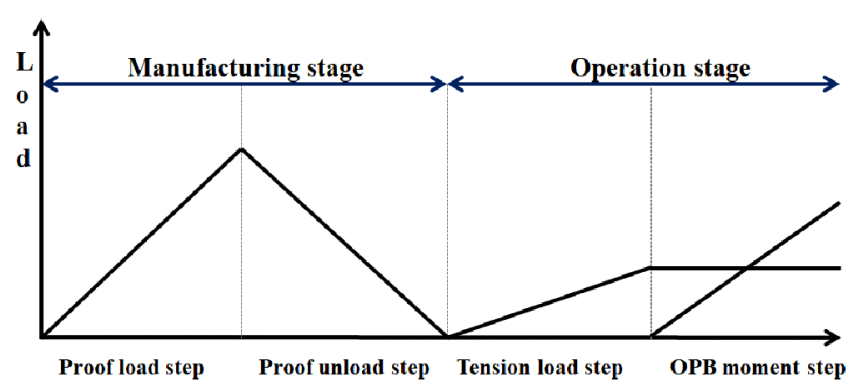

Fig. 1 Four load steps of chain link (Choung and Lee, 2018)

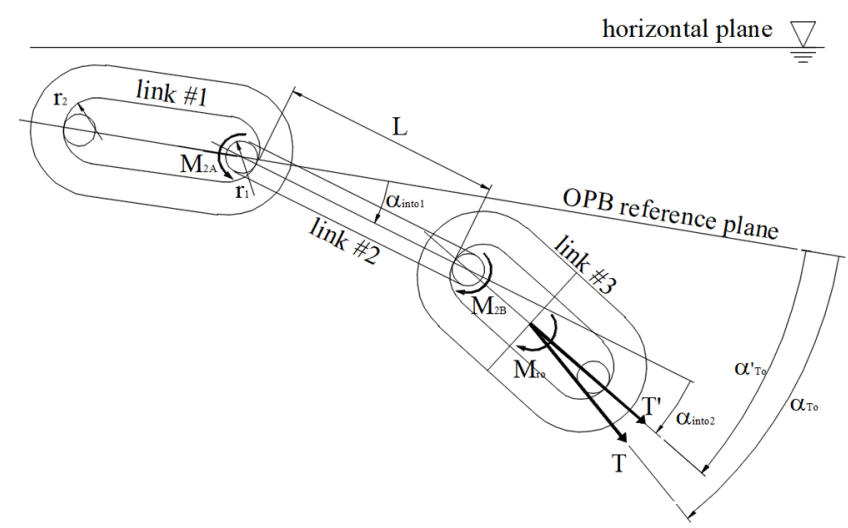

Fig. 2 Schematic of three links for OPB / IPB moment mechanism (Choung and Lee, 2018)

었다고 가정된다. 링크 \#2는 $\mathrm{OPB}$ 모멘트를 경험하는 링크이다. 링크 \#2의 $\mathrm{OPB}$ 모멘트는 링크 \#1과 링크 \#3과의 마찰력에 의하 여 발생한다. 즉 링크 \#2는 링크 \#1의 마찰력에 의하여 지지되 고, 링크 \#3에 의하여 횡하중이 가해지는 외팔보로 간주될 수 있다. 인장력 $T$ 의 외팔보에 직교하는 성분이 $\mathrm{OPB}$ 모멘트를 유 발하므로, 식 (1)과 같이 $\mathrm{OPB}$ 모멘트를 정의할 수 있다. 여기서 $\alpha_{T o}$ 는 인장력 $T$ 의 인장각을, $\alpha_{i n t o 1}$ 는 링크 \#1과 링크 \#2사이의 인터링크 각(첫 번째 인터링크 각), $L$ 은 외팔보(링크)의 길이이 다. DTA는 이러한 $\mathrm{OPB}$ 모멘트 발생 기구를 유발하도록 개발된 방법이다.

$$
\begin{aligned}
& M_{o}=T L \sin \left(\alpha_{T o}-\alpha_{i n t o 1}\right) \\
& M_{o}=M_{r o}+T^{\prime} L \sin \left(\alpha_{T o}^{\prime}-\alpha_{i n t o 1}\right)
\end{aligned}
$$

Fig. 2에 보인 바와 같이 링크 \#3과 평행한 인장력 $\left(T^{\prime}\right)$ 을 부여 한 후 강제 회전에 의한 반력 모멘트(Reaction moment, $M_{r o}$ )를 유발시키는 방법이 PRA이다. 반력 모멘트는 OPB 모멘트의 주 요 성분이므로 식 (2)의 우측 두번째 항은 종종 무시되기도 한 다. 식 (2)에서 $T^{\prime}$ 는 링크 \#3와 항상 평행한 가상의 인장력이며, $\alpha^{\prime}{ }_{T o}$ 는 인장력 $T^{\prime}$ 의 인장각을 의미한다.

\section{2 $\mathrm{OPB}$ 를 고려한 피로 해석 절차}

Choung and Lee(2018)는 3-링크 해석(Fig. 3(a) 참조)을 통한 계류 체인 링크의 OPB 피로 파손 예측 절차를 제시하였다(Fig. 4 참조). 이 절차의 첫 번째는 유체동역학 해석을 통하여 계류 선에 작용하는 인장력 및 인장각의 시계열 데이터를 확보하는 것이다. 시계열 데이터를 바탕으로 인장력 및 인장각의 최대값 및 최소값을 확보한다. 인장력 및 인장각 범위를 적절한 개수로 등분하여 각 등분점마다 3-링크 해석을 수행하여 인터링크 각 에 따른 국부 응력(Hotspot stress)을 산정한다. 통상 최대 주응력 을 국부 응력으로 간주한다. Fig. 4에서 노란색 셀은 3-링크 해 석 및 다중-링크 해석 과정을 의미한다. 인터링크 각에 따른 국 부 응력을 Fig. 5에 3차원으로 도식화하였다. 여기서 $\alpha_{T i}$ 는 면 내 굽힘(In-plane bending, IPB) 인장각을, 하 첨자 $j$ 는 증분 순서 를 의미한다. 


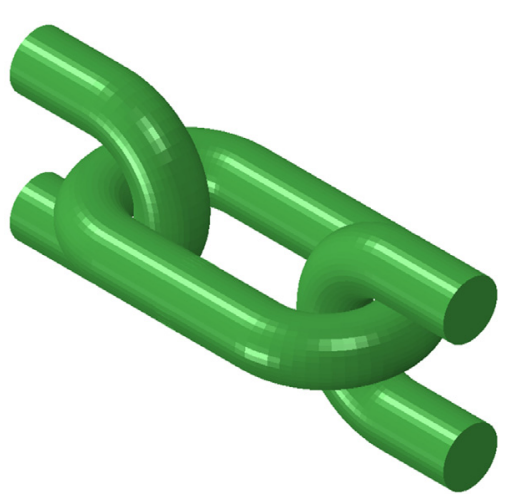

(a) 3-link model

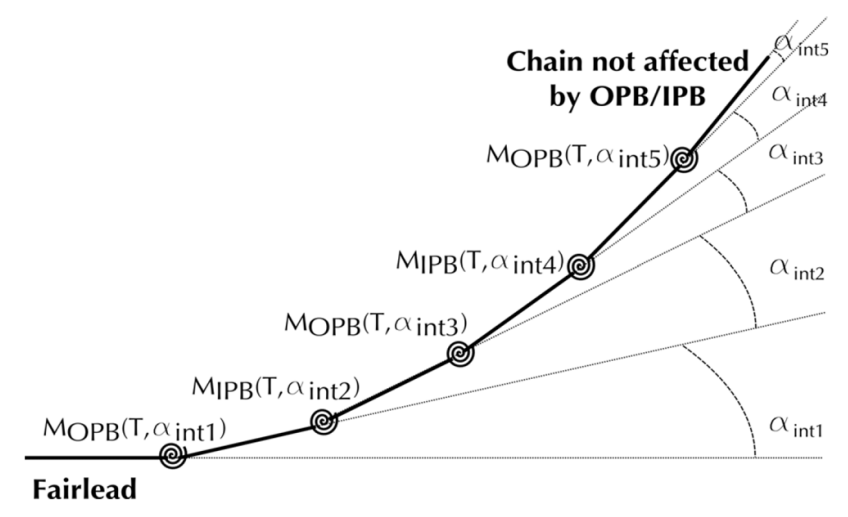

(b) multi-link model(BV, 2014)

Fig. 3 3-link and multi-link analysis models

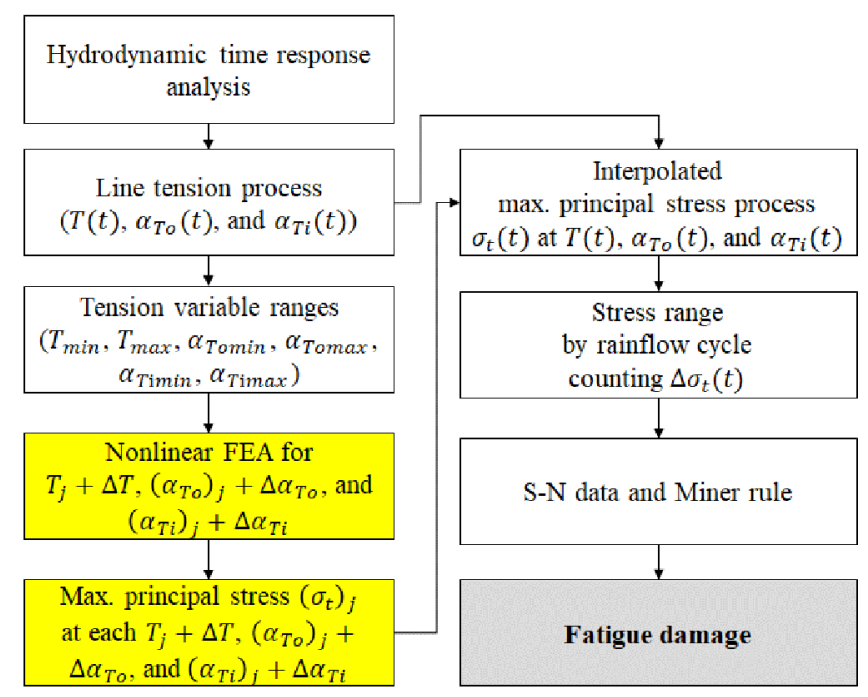

Fig. 4 Flowchart for OPB moment-induced fatigue damage prediction (Choung and Lee, 2018)
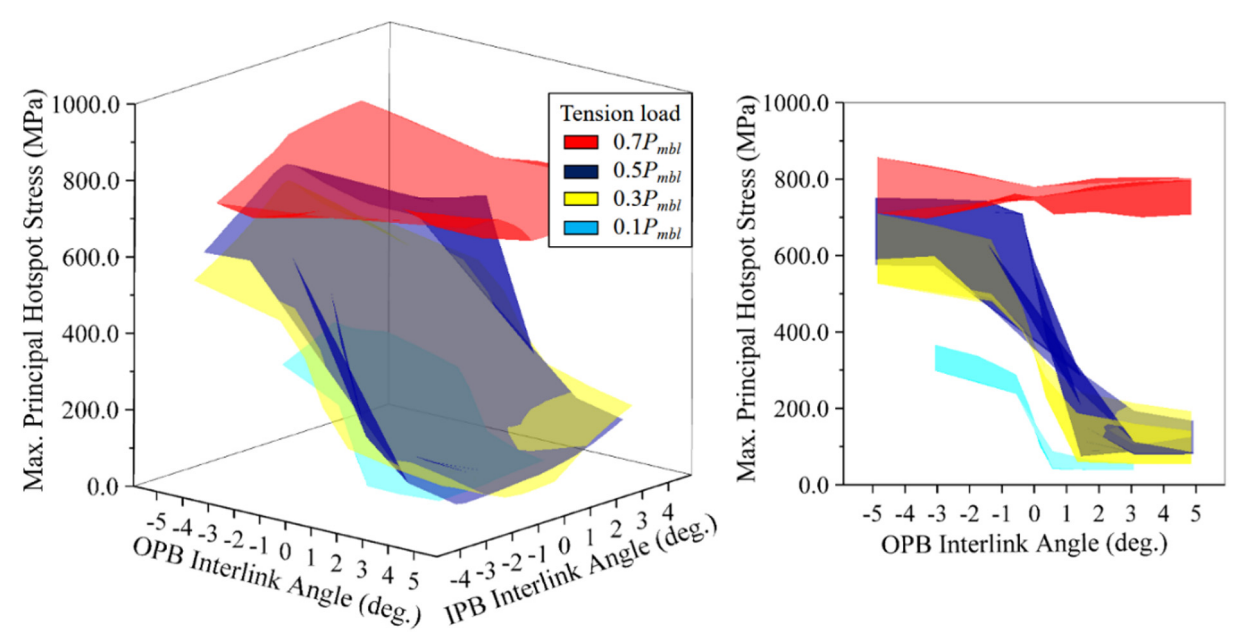

Fig. 5 Response surface of hotspot stresses as function of OPB- and IPB-interlink angles (Choung and Lee, 2018)

3-링크 해석을 통하여 얻은 국부 응력은 인터링크 각의 함수 이기 때문에 다중-링크 해석을 통하여 인터링크 각과 인장각의 관계를 도출할 필요가 있다. Fig. 3(b)에 보인 바와 같이 통상 수 개 이상의 링크를 포함하도록 다중-링크 해석 모델을 생성한다. 각 링크 사이에 비선형 스프링 요소를 배치하고, 3-링크 해석에
서 얻은 $\mathrm{OPB}$ 강성을 스프링 요소의 회전 강성으로 정의한다. 3링크 해석에서 얻은 인터링크 각-국부 응력의 관계와 다중-링크 해석에서 얻은 인터링크 각-인장각의 관계를 결합하여 비로소 인장각-국부 응력의 관계가 완성된다. 이러한 과정을 Fig. 6에 제시하였다. $\mathrm{OPB}$ 모멘트에 $\mathrm{OPB}$ 응력 집중 계수 $\left(\zeta_{o}\right)$ 를 곱하고, 


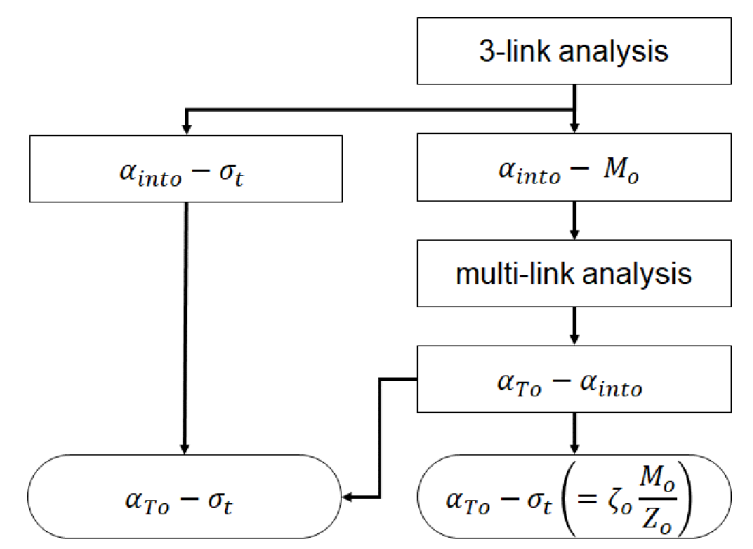

Fig. 6 Flowchart for relationship of hotspot stress-interlink angle using 3-link analysis and multi-link analysis

이를 링크의 $\mathrm{OPB}$ 단면 계수 $\left(Z_{o}\right)$ 로 나누어 국부 응력을 도출하 는 방법이 제시되어 왔다(BV, 2014). 그러나 국부 지점에서 응 력 집중 계수는 인장력 또는 인장각(인터링크 각)에 따른 비선 형성을 보여주므로, 비선형 응력 집중 계수를 확보하지 않는 한 권장되는 국부 응력 산정법이 아니다.

\subsection{3-링크 해석법 고찰}

이미 설명한 바와 같이, 3-링크 해석은 인터링크 각-국부 응력 또는 인터링크 각-OPB 모멘트 (OPB 강성)를 도출하기 위하여 수행
Table 1 Information for nominal size D107 chain link

\begin{tabular}{cc}
\hline \hline Item & Value \\
\hline Nominal diameter $D[\mathrm{~mm}]$ & 107.00 \\
Material grade & $\mathrm{R} 4$ \\
Proof load $P_{p f}$ & $7,790.40$ \\
Minimum breaking load $P_{m b l}[\mathrm{kN}]$ & $11,118.00$ \\
Axial stiffness $K_{a}[\mathrm{kN}]$ & $9.78 \mathrm{E} 5$ \\
Elastic modulus $E_{L}[\mathrm{GPa}]$ & $206.00[\mathrm{kN}]$ \\
Nominal yield strength $S_{y 0}[\mathrm{MPa}]$ & 581.63 \\
Nominal tensile strength $S_{y u}[\mathrm{MPa}]$ & 860.01 \\
Strength coefficient $K[\mathrm{MPa}]$ & 1313.41 \\
Work hardening exponent $n$ & 0.14 \\
\hline
\end{tabular}

된다. 3-링크 해석 모델은 통상 고체 요소(Solid element)로 구성되 며, 용이한 접촉 조건의 구현과 링크 표면 응력의 도출을 위하여 고체 요소 표면에 막 응력 요소(Membrane element)를 코팅한다.

3-링크 해석의 링크\#1과 링크 \#3은 길이 방향으로 대칭 모델 을 사용한다. Fig. 1에서 보는 바와 같이 검사 하중 스텝, 검사 하중 제하 스텝, 인장력 스텝은 링크의 길이 방향 하중이므로 동일한 경계 조건이 적용되지만, $\mathrm{OPB}$ 모멘트 스텝에는 별도의 경계 조건이 적용되어야 한다. 3-링크 해석에 적용되는 경계 조 건 및 하중 조건을 정리하여 Table 1에 제시하였다.

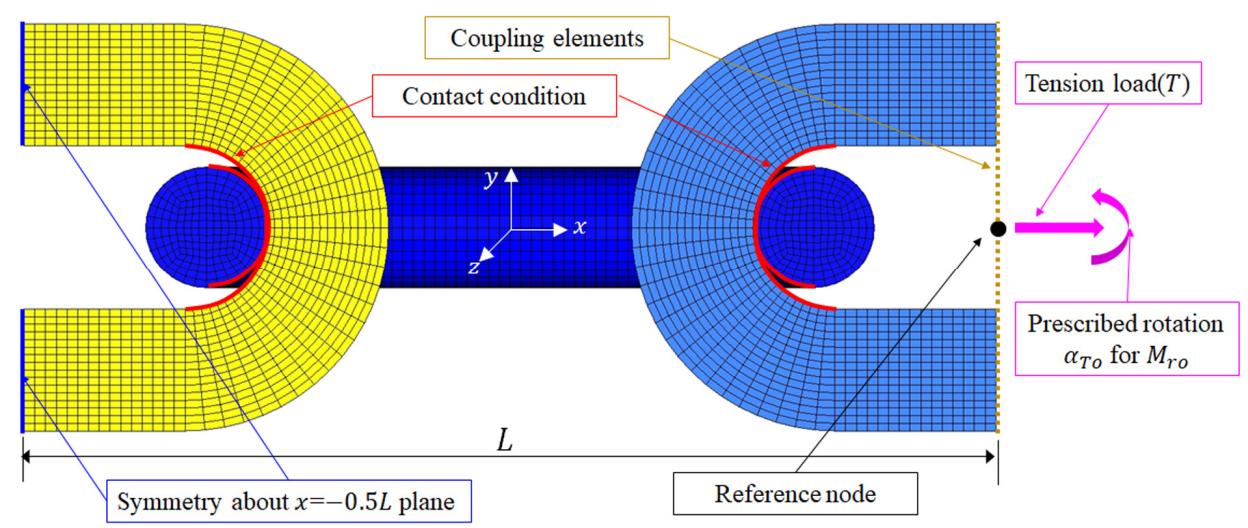

(a) PRA

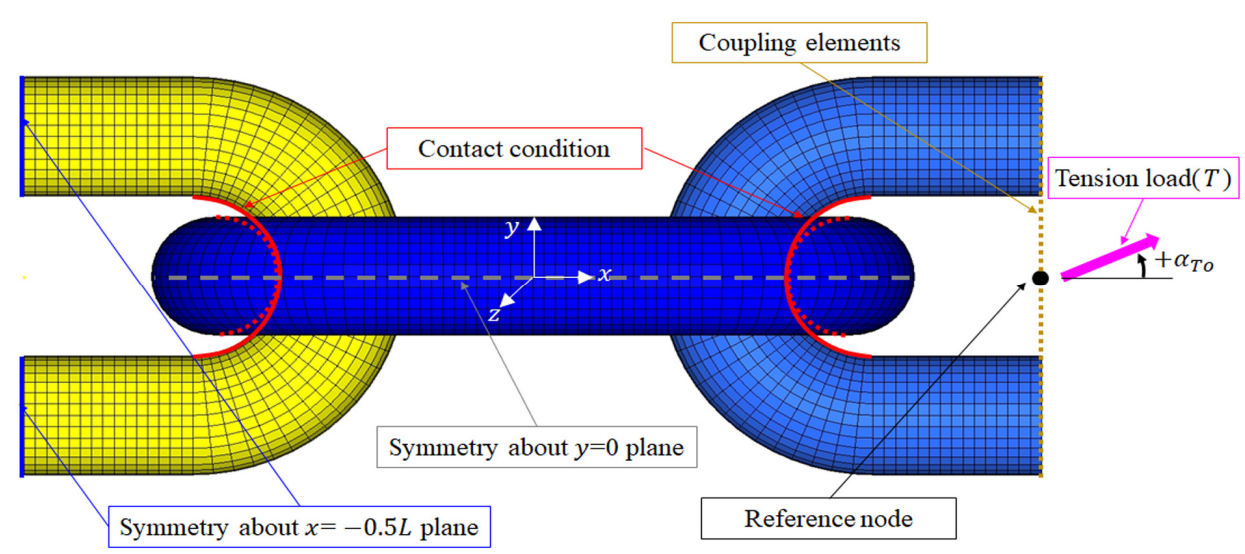

(b) DTA

Fig. 7 Comparison of boundary and loading conditions (Choung and Lee, 2018) 


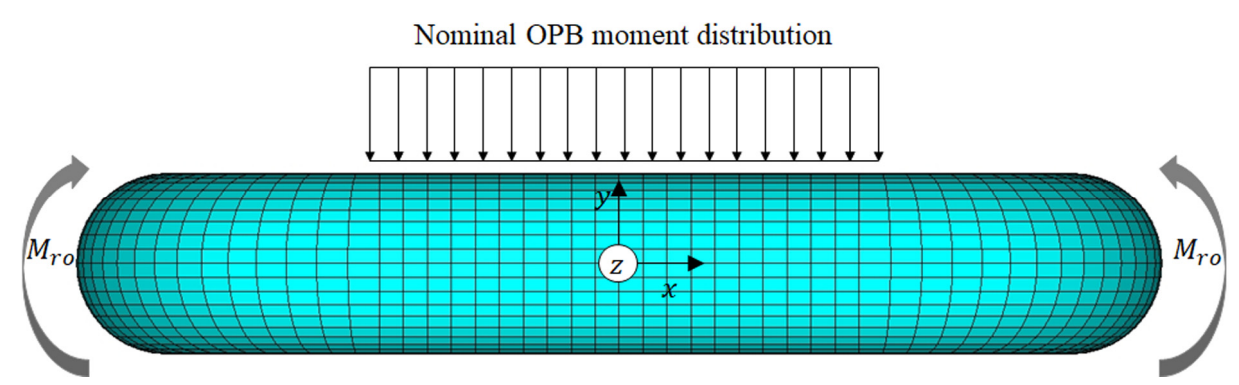

(a) PRA

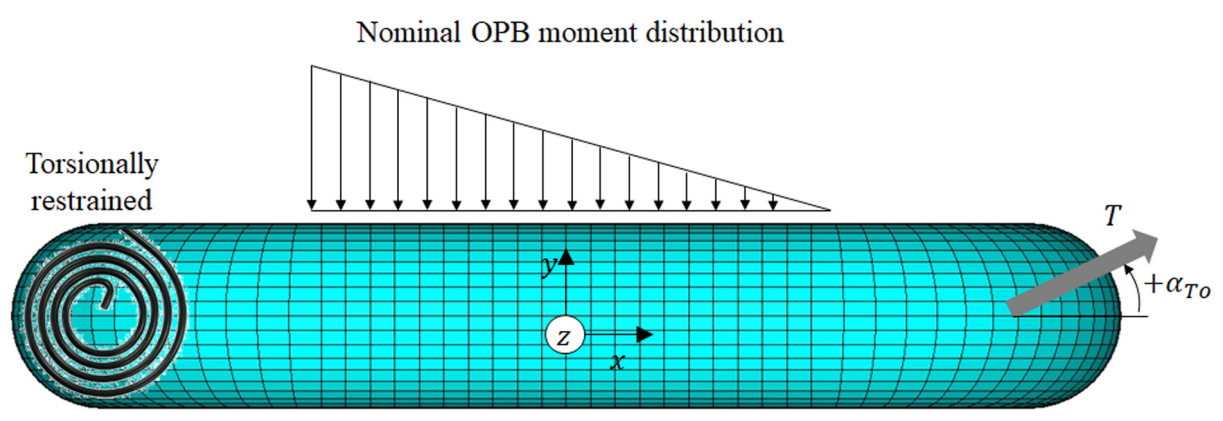

(b) DTA

Fig. 8 Illustration of OPB moment distribution in the PRA and DTA (Choung and Lee, 2018)

Fig. 7(b)에 보인 바와 같이 DTA에서는 링크 \#3에 인장각을 가지는 인장력을 가하여 $\mathrm{OPB}$ 모멘트를 유발시킨다. 반면, PRA 의 $\mathrm{OPB}$ 모멘트는 강제 회전에 의하여 생성되기 때문에, 이는 실제 구조물에서의 $\mathrm{OPB}$ 모멘트 생성 기구로 간주되기 어렵다.

링크 \#2에서의 OPB 모멘트 분포를 이상화하여 Fig. 8에 제시 하였다. 실제 계류선에서 강제 회전이 작용할 수 없기 때문에 $\mathrm{OPB}$ 모멘트는 Fig. 8(b)와 같이 분포할 것이다. 그러나 PRA를 적용할 경우 Fig. $8(\mathrm{a})$ 와 같이 $\mathrm{OPB}$ 모멘트가 분포한다. 이러한 이유로 DTA는 현실과 유사한 $\mathrm{OPB}$ 모멘트 발생 기구를 가지는 것이다.

인장력 또는 강제 회전은 링크 \#3의 우측에 참조 절점 (Reference node)에 부여된다. 이때 인장력 또는 강제 회전 변위를 링크 절점에 전달하기 위하여 변위 커플링(Kinematic coupling) 또 는 하중 커플링(Distributing coupling)이 적용된다. 하중 커플링은
링크 \#3의 우측 대칭면이 평면을 유지하지 못하게 때문에 권장되 지 않는다. 변위 커플링을 사용할 경우 앞의 세 스텝과 OPB 모멘 트 스텝에 적용되는 참조 절점과 종속 절점 사이의 종속성 (Dependency)이 서로 다르기 때문에, 해석 도중 모델을 변경하는 고도의 수치 해석 기법이 요구된다. Choung and Han(2016a)와 Choung and $\operatorname{Han}(2016 \mathrm{~b})$ 는 선행 하중 스텝의 변위, 응력, 변형률 등의 정보만을 후행 스텝에서 상속받아 새로운 변위 커플링 종속 조건을 정의하는 기법을 제시한 바 있다.

\section{4 다중-링크 해석법 고찰}

시간 영역 유체동력학 해석으로부터 인장력 이력 및 인장각 이 력, 3-링크 해석으로부터 $\mathrm{OPB}$ 강성을 얻은 후, 인장각-OPB 모멘트 관계를 도출하기 위하여 다중-링크 해석이 요구된다. Fig. 3(b)에 보인 바와 같이, 선행하는 인터링크 각도는 후행하는 인터링크 각

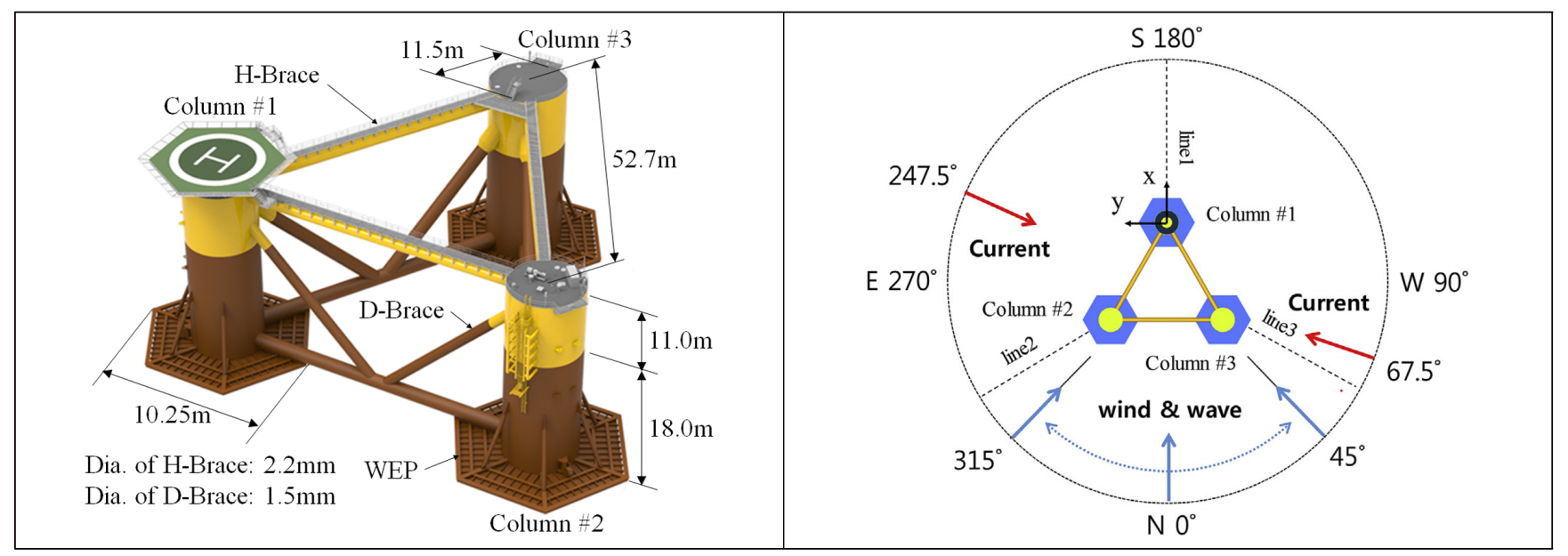

Fig. 9 8MW floating offshore wind turbine platform 
도보다 크다. 예를 들어 $m$ 개의 링크가 있다면, $\alpha_{i n t o 1}>\alpha_{i n t o 2}>$ $\alpha_{i n t o 3 \ldots}>\alpha_{(i n t o(m-1)}$ 의 관계가 성립된다. $\alpha_{i n t o(m-2)} \approx \alpha_{i n t o(m-1)}$ 을 만족하도록 충분히 많은 링크의 개수가 다중-링크 해석에 사용되 어야 한다. BV(2014)에 의하면 20개 이상의 링크를 사용할 것을 권장한다.

\section{3. 벤치마크 스터디}

\section{1 벤치마크 스터디 모델}

벤치마크 스터디를 위하여 $8 \mathrm{MW}$ 급 해상 풍력 발전기에 사용 된 계류선을 대상으로 적용하였다(Li et al., 2018). 해상 풍력 발 전기 형상은 Fig. 9와 같다. 이들이 사용한 링크의 호칭 지름 (Nominal diameter)은 $100 \mathrm{~mm}(\mathrm{D} 100)$ 였으나, 본 연구에서는 $107 \mathrm{~mm}$ (D107)로 가정하였다. 또한 링크의 소재 등급은 R4였다. 호칭지 름과 등급을 이용하여 검사 하중 $\left(P_{p f}\right)$, 최소 파단 하중 $\left(P_{m b l}\right)$, 단 위 길이당 축 강성(Axial stiffness, $K_{a}$ )을 Table 1 에 제시하였다 (DNV, 2010). 또한 Table 1에 제시된 강도 계수 $(K)$ 와 가공 경화 계수 $(n)$ 를 계수로 가지는 멱 법칙(Power law)를 이용하여 소재 의 유동 응력(Flow stress)를 정의하였다.

\subsection{3-링크 해석}

\subsubsection{3-링크 모델링}

Fig. 3(a) 및 Fig. 7에 제시된 구조 해석 모델을 벤치 마크 스터 디의 3-링크 해석에 적용하였다. 상용 해석 프로그램 ABAQUS V6.8을 이용하여 3-링크 해석이 수행되었다. 굽힘에 대한 비적합 성을 개선한 8 면체 감차 적분 고체 요소(C3D8RI)를 이용하여 링 크를 모델링하였다. 링크 표면에서의 신뢰성 있는 응력 확보와 링크 간 용이한 접촉을 구현하기 위하여, 무시할 만한 두께를 가 지는 감차 적분 막 응력 요소(M3D4R)를 링크 표면에 코팅하였 다. 3 번 링크의 우측에 위치한 참조 절점과 링크의 단면에 배치 된 종속 절점을 변위 커플링 요소로 결합하였다. 이때 1 번 스텝 부터 3 번 스텝까지의 참조 절점과 종속 절점 사이에 $\mathrm{x}$-평면 대칭 종속성을 부여하였다. 반면 마지막 하중 스텝(OPB 스텝)에서 완 전 구속 종속성을 부여하였다(Choung and Han, 2016a; Choung and Han, 2016b; Choung and Lee, 2018). 3-링크 해석을 위하여 적 용된 요소 개수를 Table 2에 정리하였다.

3-링크 해석의 첫번째 스텝에 Table 1 에 제시된 $P_{p f}$ 가 적용되 었으며, 두번째 스텝에서 $P_{p f}$ 가 제거되었다. 세번째 스텝에서 실
Table 2 Summary of the number of elements.

\begin{tabular}{cc}
\hline \hline Element Type & Number of element \\
\hline C3D8I & 60,000 \\
M3D4R & 8,000 \\
Displacement coupling & 1 \\
Sum & 68,001 \\
\hline
\end{tabular}

제 인장력 $(T)$ 이 참조 절점에 부여되었다. 3-링크 해석 결과는 인 장력과 인장각의 크기에 따라 변동적이다. 실제 인장력의 크기 는 $P_{m b l}$ 을 초과할 수 없지만, 계류선에 작용하는 인장력이 0.5 $P_{m b l}$ 을 초과하지 않도록 안전율을 가지도록 설계하는 것이 일반 적이다. 본 연구에서는 $T=0.1 P_{m b l}, 0.3 P_{m b l}, 0.5 P_{m b l}$ 을 계류 체인 링크에 작용하는 인장력으로 결정하였다. 네 번째 스텝에서 $\mathrm{OPB}$ 첫 번째 인터링크 각 $\left(a_{i n t o 1}\right)$ 이 5도 이상 발생하도록 인장각을 부 여하였다. 각 스텝별로 적용한 경계 조건을 Table 3에 정리하였 다. 해수 윤활 조건을 감안하여 링크 간의 마찰 계수 $\mu=0.3$ 을 적 용하였다(BV, 2014).

\section{2 .2 3-링크 해석 결과}

링크 \#2의 중앙부 단면의 응력을 압축과 인장으로 나누어 Fig. 10 에 제시하였다. $0.5 P_{m b l}$ 의 인장력을 적용했을 경우 응력 분포는 Fig. 10(a)와 같다. 검사 하중 제하 후에 중앙부 단면에 전체적으로 남아있던 압축 잔류 응력이 인장력에 의하여 대부 분 인장 응력으로 변하고, 단면 외곽 일부에 압축 응력이 잔존 하는 것을 Fig. 10(a)에서 확인이 가능하다. 순수 인장력 작용할 때 링크 \#2의 평행부가 안쪽으로 가까워지는 방향(z-방향)으로 변형하기 때문에, 단면 외곽에 압축 응력이 존재하는 것으로 추 정된다.

$\mathrm{DTA}$ 에 기반한 $\mathrm{OPB}$ 모멘트를 작용시킬 경우 링크 \#2의 압축 응력 분포는 비교적 적게 변하는 것을 Fig. 10(b)로부터 확인이 가능하다. 반면, $\mathrm{PRA}$ 에 기반한 $\mathrm{OPB}$ 모멘트를 작용시킬 경우 링 크 \#2의 $\mathrm{y}$-방향 하부까지 압축 응력이 발달하는 것을 Fig. 10(c) 에서 확인할 수 있다. 이는 해석 방법에 따라서 링크 \#2 응력의 분포가 크게 변동적이라는 증거이다.

Fig. 11(a), (b), (c)는 각각 $P_{m b l}$ 의 $10 \%, 30 \%, 50 \%$ 를 인장력으 로 작용시킬 때, DTA, PRA, BV 가이드라인을 이용하여 계산된 $\mathrm{OPB}$ 강성을 나타낸다. 이때 적용한 $\mathrm{BV}$ 가이드라인을 식 (3)에

Table 3 Applied load and boundary conditions in the DTA (Choung and Lee, 2018)

\begin{tabular}{lcccc}
\multicolumn{1}{c}{ Condition } & \multicolumn{2}{c}{ Load step } \\
& Proof load & Proof unload & Tension load & OPB moment \\
\hline Symmetry at $x=0.5 L$ plane & $\sqrt{ }$ & $\sqrt{ }$ & $\sqrt{ }$ & $\sqrt{ }$ \\
Symmetry at $y=0$ plane & $\sqrt{ }$ & $\sqrt{ }$ & $\sqrt{ }$ \\
Symmetry at $z=0$ plane & & & $\sqrt{ }$ \\
$u_{y}=u_{z}=0$ at $x=0.5 L$ plane & $\sqrt{ }$ & & $\sqrt{ }$ \\
Proof load $P_{p f}$ \\
$\begin{array}{l}\text { Pure tension } \\
\text { Oblique tension with } \alpha_{T o} \text { for DTA Prescribed rotation for PRA }\end{array}$ & & & $\sqrt{ }$ \\
\hline
\end{tabular}




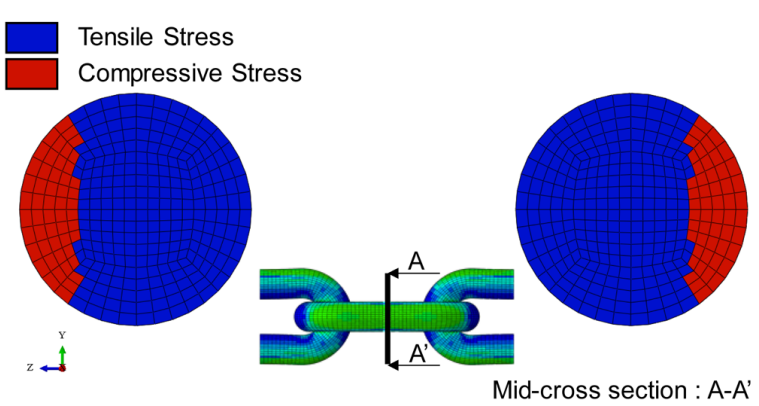

(a) at the end of tension load step

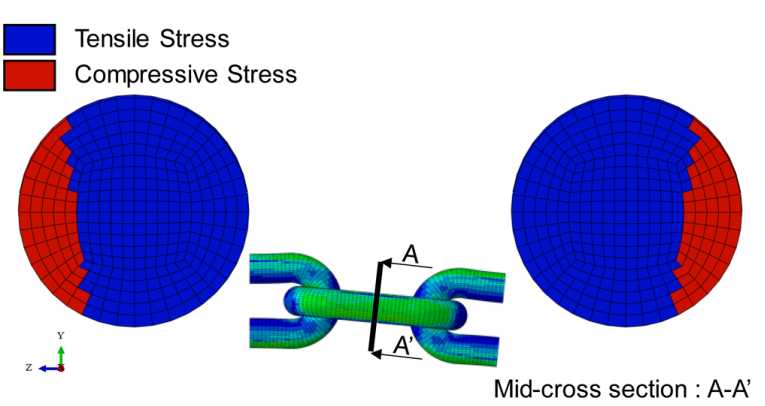

(b) in the middle of OPB moment step based on $\operatorname{DTA}\left(\alpha_{\text {into } 1}=1.5^{\circ}\right)$

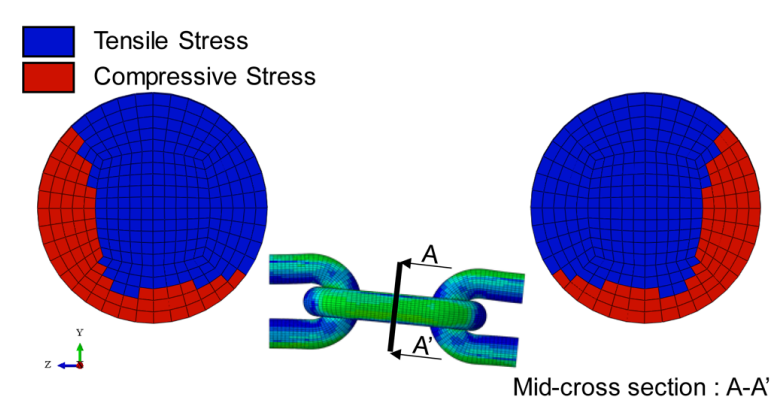

(c) in the middle of OPB moment step based on $\operatorname{PRA}\left(\alpha_{\text {into } 1}=1.5^{\circ}\right)$

Fig. 10 Tensile and compressive stress distributions in mid-span section of the link \#2 (Lee et al, 2018)

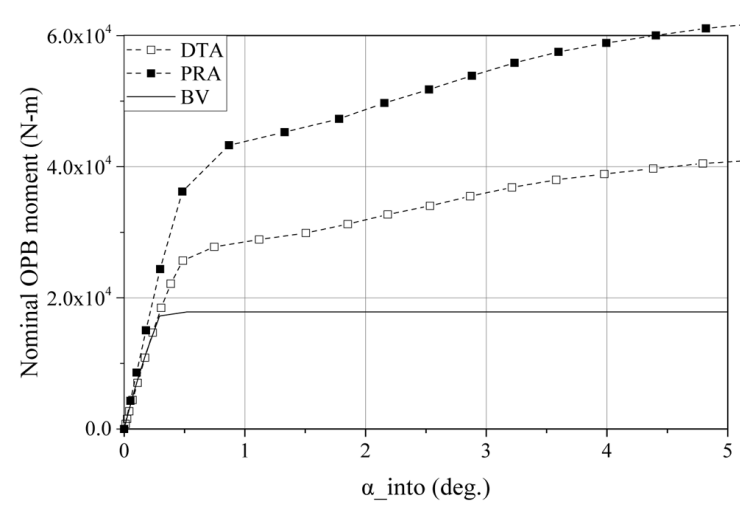

(a) $T=0.1 P_{m b l}$

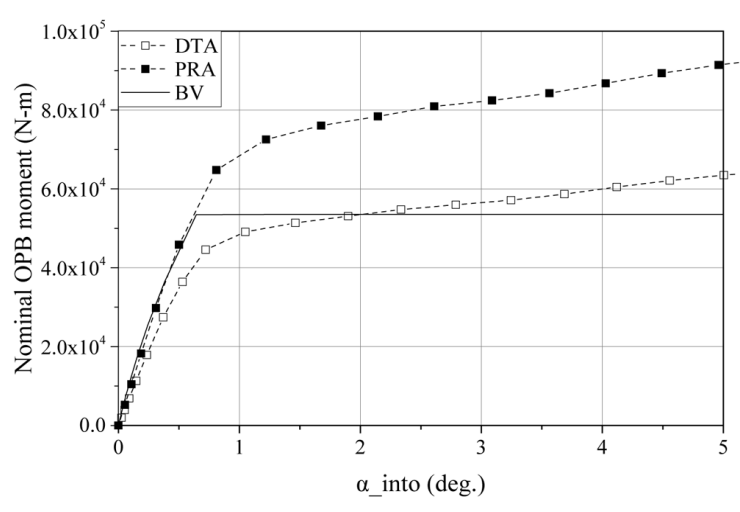

(b) $T=0.3 P_{m b l}$

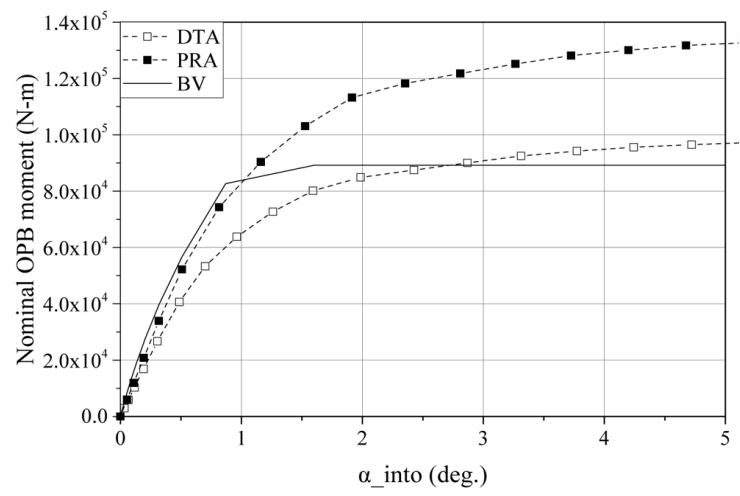

(c) $T=0.5 P_{m b l}$

Fig. 11 OPB stiffness curves in the link $\# 2$

정리하여 나타냈다. 인장력이 가장 작을 때 $\left(0.1 P_{m b l}\right)$ 를 제외하고, $\mathrm{DTA}$ 기반 $\mathrm{OPB}$ 강성이 $\mathrm{BV}$ 가이드라인 기반 결과와 비교적 유 사한 것을 확인할 수 있다. 반면 $\mathrm{PRA}$ 기반 $\mathrm{OPB}$ 강성은 인장력
크기에 관계없이 크게 예측되었다. $\mathrm{BV}$ 가이드라인에 의한 구속 모드 강성(Locking mode stiffness)는 PRA 기반 결과와 상당히 일치하는 경향을 나타낸다. 식 (3)은 경험식임을 감안할 때 PRA 


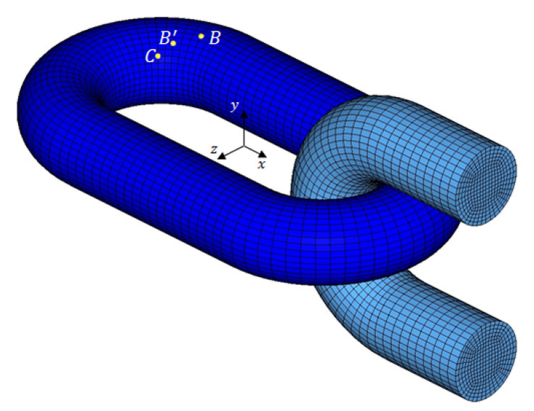

(a) iso view

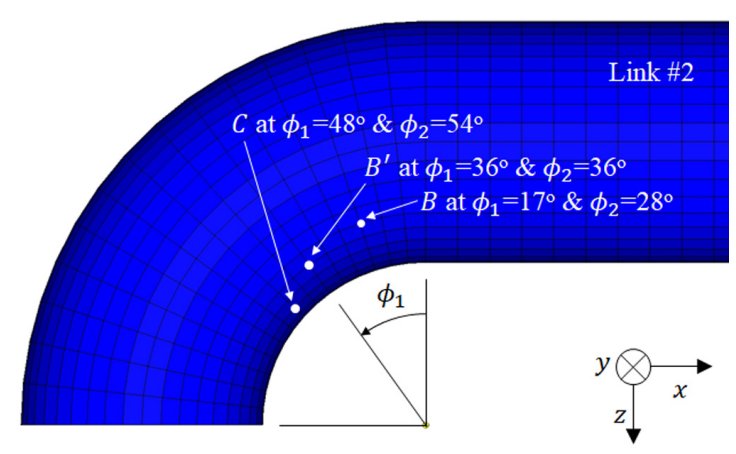

(b) y-view

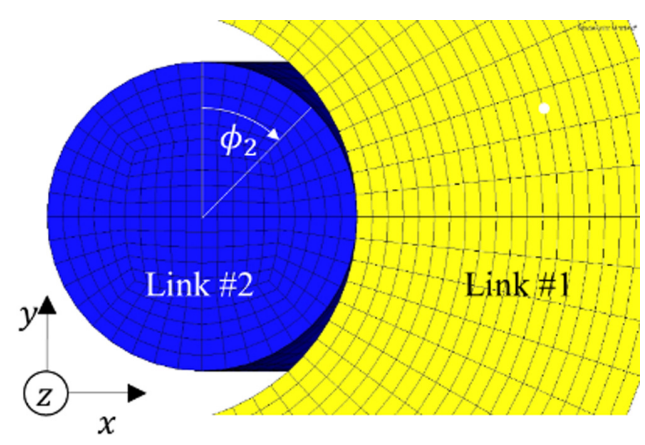

(c) z-view

Fig. 12 Hotspot locations in link \#2 (Choung and Lee, 2018)

기반으로 도출되었을 것으로 추정된다. 또한 식 (3)에 기반한 미끌림 모드 강성은 인장력 크기에 관계없이 0 에 수렴하는 것 을 확인할 수 있다. 반면 PRA 및 DTA 기반 미끌림 강성은 무 시할 수 없고, 더욱이 구속 모드에서 미끌림 모드로의 천이를 명확하게 구분할 수 없다. 이러한 경향은 낮은 인장력에서 더 뚜렷하다. 낮은 인장력에서 마찰에 의한 구속력도 작기 때문에 이 경향은 물리적으로 타당한 결과로 사료된다.

$$
M_{o}=\frac{354 \pi D^{3}}{16} \frac{P}{0.93+P}\left(\frac{T}{0.14 D^{2}}\right)^{a}\left(\frac{D}{100}\right)^{2 a+b}
$$

where

$$
\begin{aligned}
& P\left(\alpha_{\text {into }}\right)=\alpha_{\text {into }}+0307 \alpha_{\text {into }}^{3}+0.0048 \alpha_{\text {into }}^{5} \\
& a\left(\alpha_{\text {into }}\right)=0.439+0.532 \tanh \left(1.02 \alpha_{\text {into }}\right) \\
& b\left(\alpha_{\text {into }}\right)=-0.433-1.640 \tanh \left(1.32 \alpha_{\text {into }}\right)
\end{aligned}
$$

$\mathrm{BV}$ 가이드라인이 제시하는 3 개의 국부 지점 $(\mathrm{B}, \mathrm{B}, \mathrm{C})$ 을 Fig. 12에 나타내었다(Rampi et al., 2015). 3개의 국부 지점에 대한 국부 응력과 인터링크 각의 관계를 3-링크 해석으로부터 도출 하였으며, 이를 Fig. 13에 제시하였다. 인장력 수준이 $0.1 P_{m b l}$ 일 때 $\mathrm{BV}$ 가이드라인은 국부 응력을 상당히 과소 평가하고 있음을 Figs. 13(a)-13(c)로 부터 확인할 수 있다. 링크\#1과 가장 가까운 국부 지점은 $\mathrm{C}$ 이며, 이 지점에서의 DTA 기반 국부 응력은 PRA 기반 국부 응력과 상당히 일치하는 것을 Fig. 13(c)로부터 확인 할 수 있다.
인장력이 $0.3 P_{m b l}$ 로 증가하면 오히려 $\mathrm{BV}$ 가이드라인이 국부 응력을 과소 평가하고 있음을 Fig. 13(f)로부터 확인이 가능하다. 인장력이 $0.5 P_{m b l}$ 로 증가하면 $\mathrm{BV}$ 가이드라인 기반 국부 응력은 DTA 기반 국부 응력 또는 PRA 기반 국부 응력에 비하여 엄청 나게 크다는 사실을 확인할 수 있다(Figs. 13(g)-13(i) 참조). 반면 인장력의 증가에 따라 DTA와 PRA에 의한 국부 응력은 서로 일치하는 것을 확인할 수 있다.

Fig. 13에 제시된 국부 응력에 링크 \#2의 단면 계수를 곱하고 이를 OPB 모멘트로 나누면 식 (4)와 같이 OPB 응력 집중 계수 $\zeta_{o}$ (Stress concentration factor, $\mathrm{SCF}$ )를 도출할 수 있다. 탄소성 해 석의 비선형성 및 접촉 문제의 비선형성을 고려하면 $\zeta_{0}$ 도 비선 형으로 예측된다. 이를 관찰하기 위하여 Fig. 14에 $\zeta_{0}$ 를 제시하 였다. 낮은 하중 $\left(0.1 P_{m b l}\right)$ 에서 국부 지점에 관계없이 비교적 일 정한 응력 집중 계수가 유지되는 것을 확인할 수 있다(Figs. 14(a)-14(c) 참조). 반면 인장력이 $0.3 P_{m b l}$ 로 증가할 경우, 링크 $\# 1$ 에 가장 근접한 국부 지점인 $\mathrm{C}$ 에서 $\mathrm{SCF}$ 는 상당히 비선형이 다. 인장력이 $0.5 P_{m b l}$ 로 증가할 경우, 국부 지점에 관계없이 초 기 $\mathrm{SCF}$ 를 유지하지 못하고 인터링크 각이 증가하면서 $\mathrm{SCF}$ 가 급격히 감소하는 현상을 관찰할 수 있다. $\mathrm{OPB}$ 모멘트는 꾸준히 증가하는데 비해, $\mathrm{OPB}$ 국부 응력이 급격히 감소해서 발생한 현 상이다. $\mathrm{BV}$ 가이드라인은 국부 지점에 따른 $\mathrm{SCF}$ 를 제공하고 있지만, 인터링크 각에 따라 변동하는 SCF를 제공하지 않는다. 이러한 이유로 인하여 $\mathrm{BV}$ 가이드 라인은 인장력이 증가했을 때 국부 응력을 과대 평가한다고 추정된다.

$$
\zeta_{o}=\frac{\sigma \cdot Z}{M_{o}}
$$




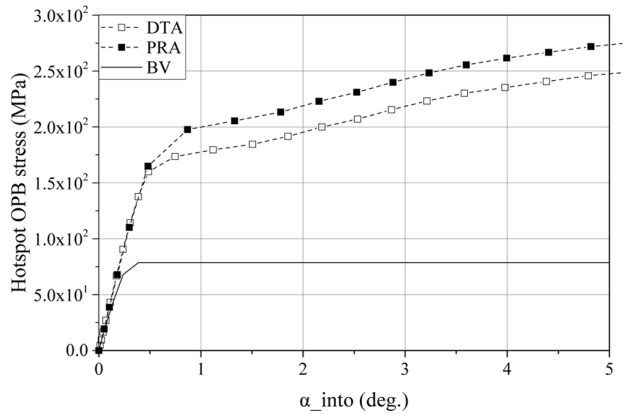

(a) Hotspot B when $T=0.1 P_{m b l}$

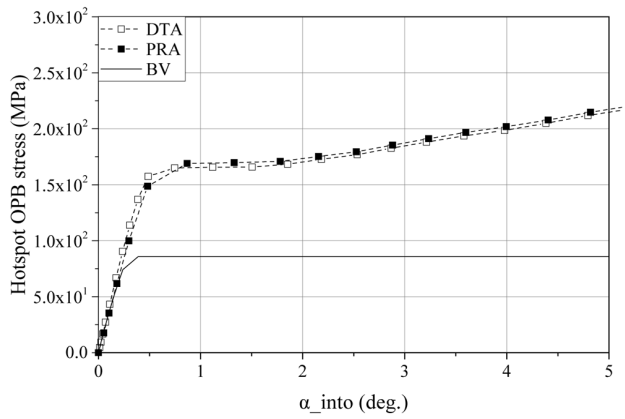

(c) Hotspot $\mathrm{C}$ when $T=0.1 P_{m b l}$

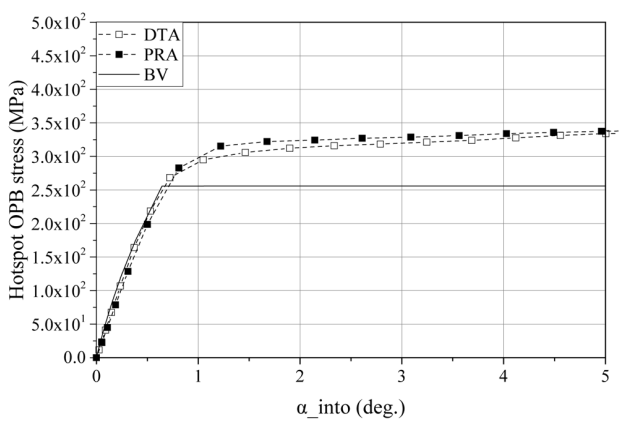

(e) Hotspot $\mathrm{B}^{\prime}$ when $T=0.3 P_{m b l}$

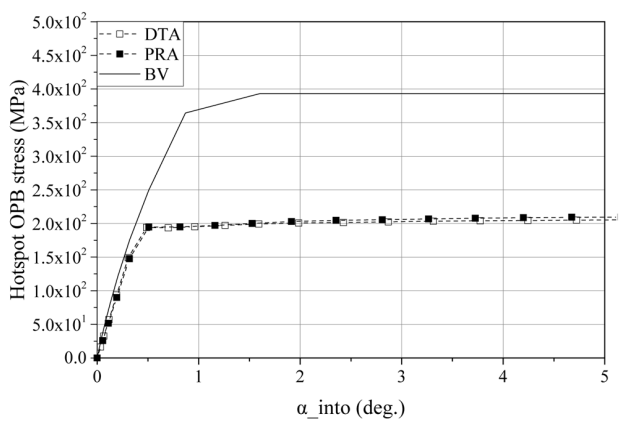

(g) Hotspot B when $T=0.5 P_{m b l}$

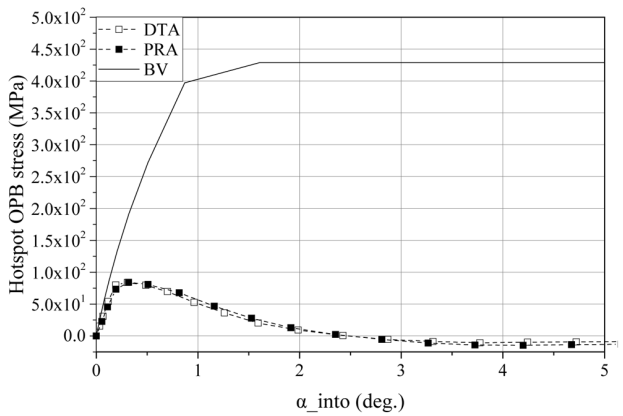

(i) Hotspot $\mathrm{C}$ when $T=0.5 P_{m b l}$

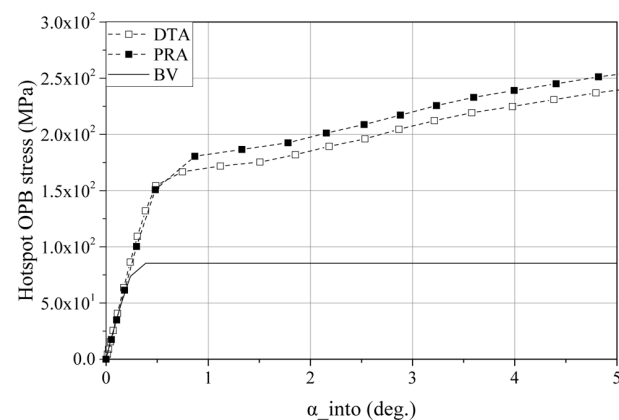

(b) Hotspot B' when $T=0.1 P_{m b l}$

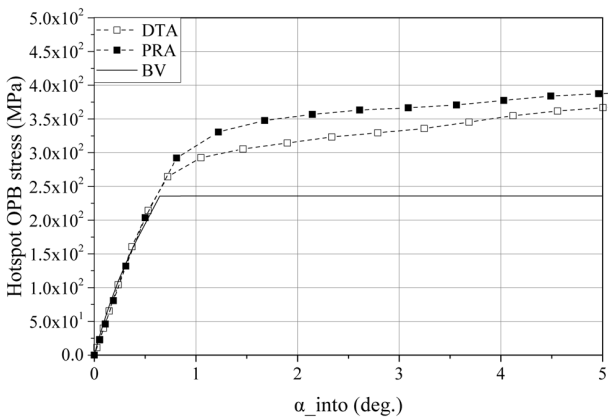

(d) Hotspot B when $T=0.3 P_{m b l}$

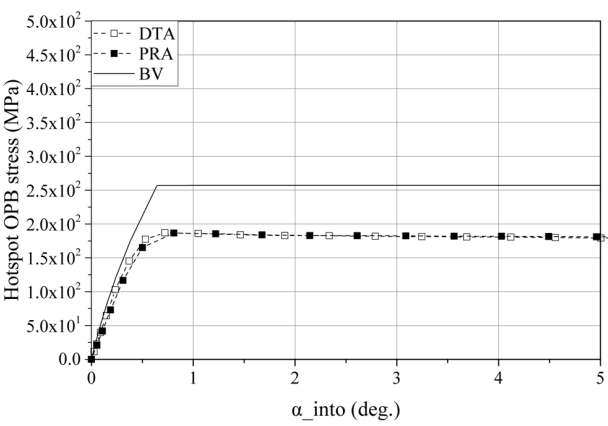

(f) Hotspot $\mathrm{C}$ when $T=0.3 P_{m b l}$

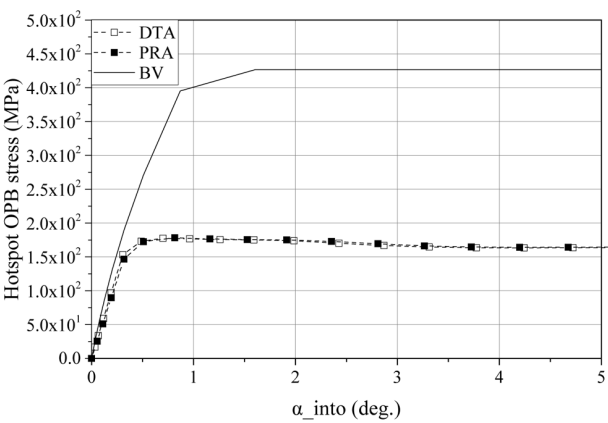

(h) Hotspot B' when $T=0.5 P_{m b l}$

Fig. 13 Relation of hotspot stress versus interlink angle 


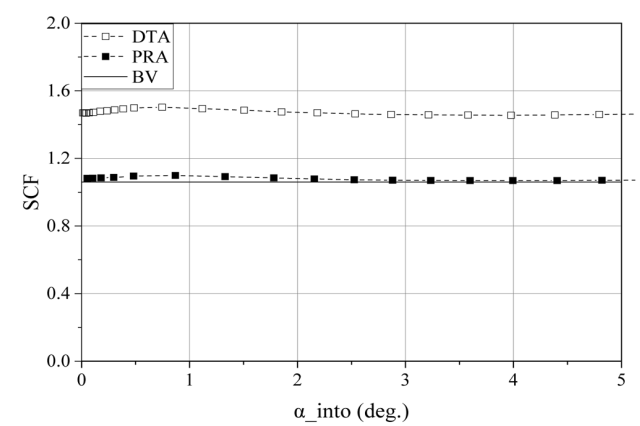

(a) Hotspot B when $T=0.1 P_{m b l}$

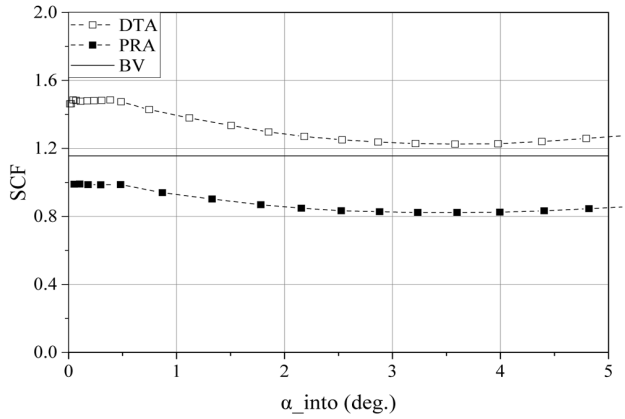

(c) Hotspot $\mathrm{C}$ when $T=0.1 P_{m b l}$

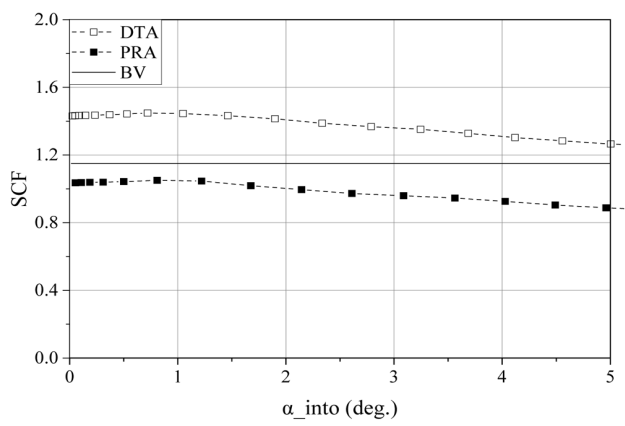

(e) Hotspot B' when $T=0.3 P_{m b l}$

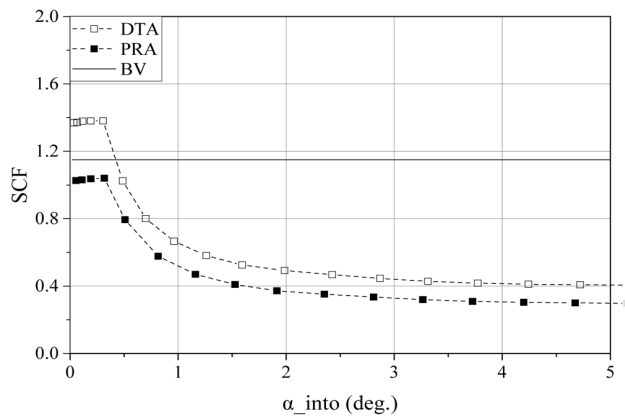

(g) Hotspot B when $T=0.5 P_{m b l}$

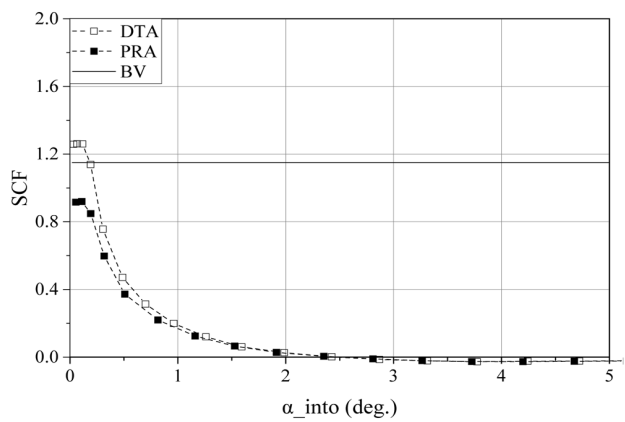

(i) Hotspot $\mathrm{C}$ when $T=0.5 P_{m b l}$

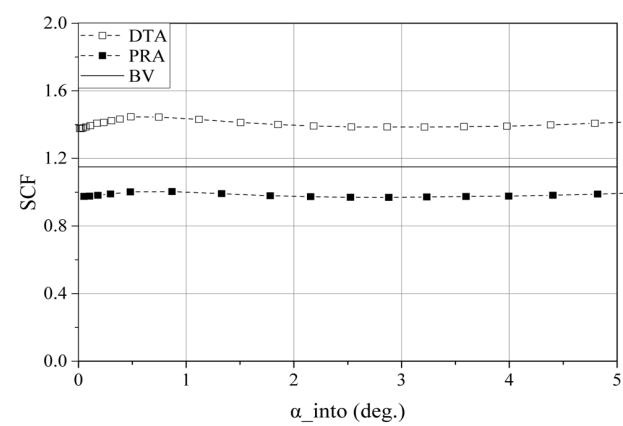

(b) Hotspot B' when $T=0.1 P_{m b l}$

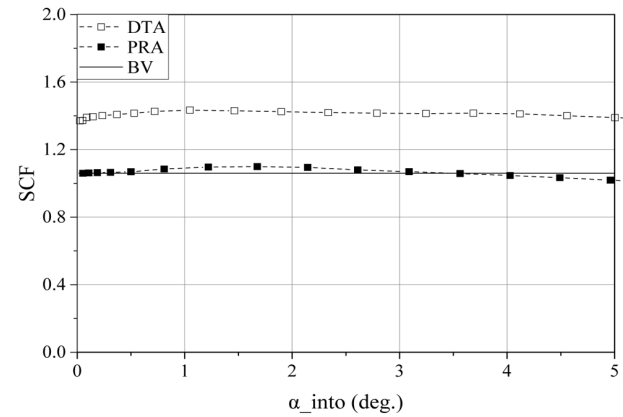

(d) Hotspot B when $T=0.3 P_{m b l}$

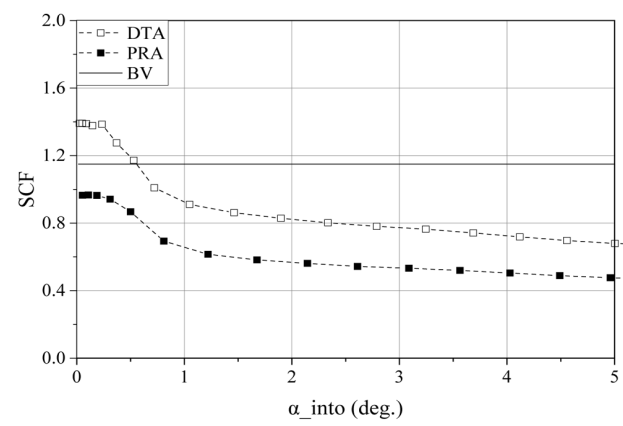

(f) Hotspot $\mathrm{C}$ when $T=0.3 P_{m b l}$

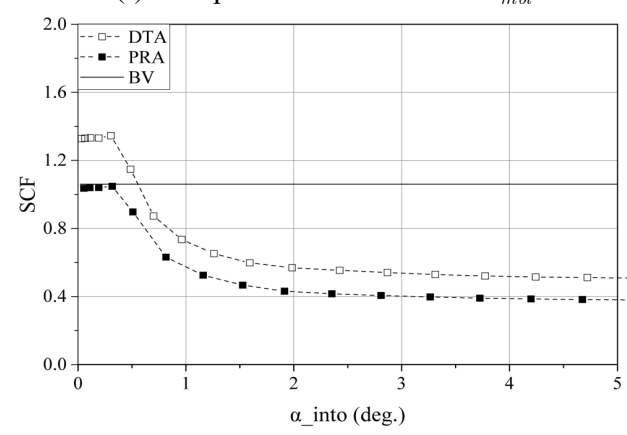

(h) Hotspot B' when $T=0.5 P_{m b l}$

Fig. 14 Relation of SCF versus interlink angle 


\section{3 다중-링크 해석}

\subsection{1 다중-링크 모델링}

Fig. 3(b)에 제시된 구조 해석 모델에 대한 링크 개수 평가를 실시하였다. 다수의 3 차원 보 요소(B31)를 이용하여 1 개 링크의 기하학적 형상을 최대한 구현하였다. 링크 1 개당 사용한 보 요 소의 개수는 직선부 4 개, 만곡부 16 개, 총 20 개이다. 3 -링크 해 석에 적용된 재료 속성을 다중-링크 해석에 적용하였다. 링크가 만나는 절점의 회전 자유도를 제거하여 링크간 회전이 가능하 도록 하였다. 이후 링크가 만나는 절점에 스프링 요소를 배치하 고 Fig. 11에 제시한 DTA 기반 OPB 강성을 부여하였다. 다중링크 해석에 적용된 경계 조건은 3-링크 해석에 적용된 경계 조 건과 동일하다. 이때 적용한 인장력은 $T=0.5 P_{m b l}$ 이며 인장각 은 $\alpha_{T o}=1.5^{\circ}$ 이다. 본 연구에서는 링크의 개수를 결정하기 위하 여 Fig. 15 와 같이 5 종류의 링크 개수(5개, 10 개, 15 개, 20 개, 25 개)를 준비하였다. 상용 해석 프로그램 ABAQUS V6.8을 이용하 여 다중-링크 해석을 수행하였다.

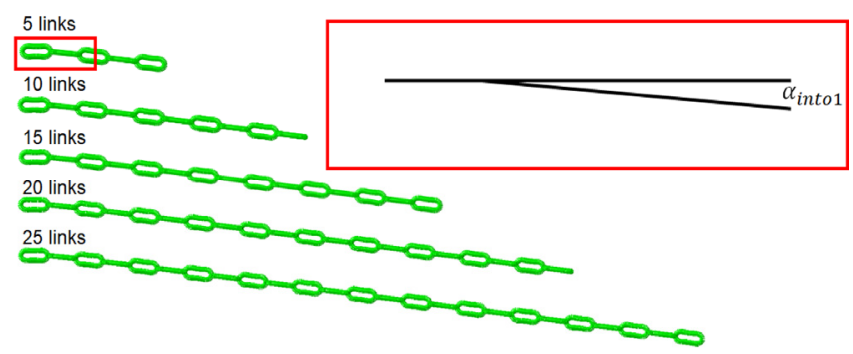

Fig. 15 Multi-link analysis models according to the number of links

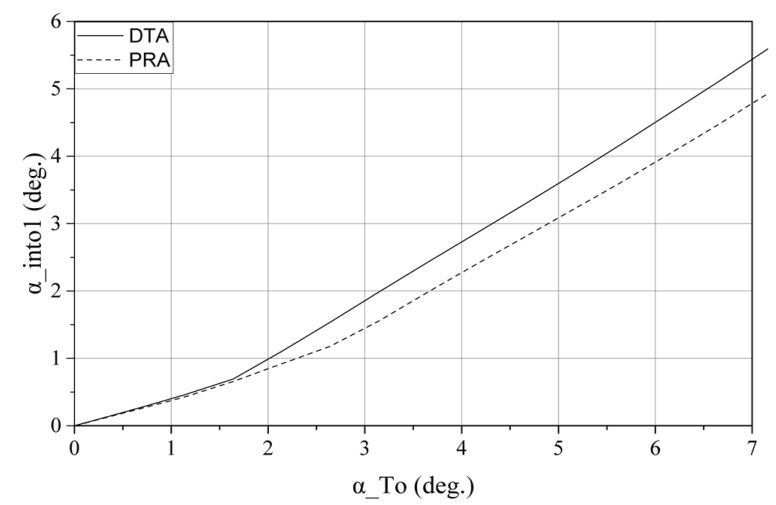

(a) $T=0.1 P_{m b l}$

\subsection{2 다중-링크 해석 결과}

Fig. 16은 링크의 개수에 따른 무차원 $a_{i n t o 1}$ (첫 번째 인터링크 각)이다. 링크의 개수가 25 개 $(m=25)$ 일 때의 $a_{i n t o 1}$ 를 정답으로 간주하고 링크 개수에 따른 $\alpha_{i n t o 1}$ 를 무차원하여 Fig. 16에 제시 하였다. 링크의 개수가 10 개 이상일 경우 수렴하는 $a_{i n t o 1}$ 을 얻 을 수 있었으며, 따라서 다중-링크 해석에 적용되는 링크의 최 소 개수는 10 개로 제안한다.

링크의 개수를 10 개로 다중-링크 해석을 수행한 후 인장각 $\left(\alpha_{T o}\right)$ 과 첫 번째 인터링크 각 $\left(\alpha_{i n t o 1}\right)$ 의 관계를 정리하여 Fig. 17 에 제시하였다. 예측한대로 $\mathrm{DTA}$ 기반 $\mathrm{OPB}$ 강성을 적용한 $\alpha_{T o}$ $a_{i n t o 1}$ 의 관계는 PRA 기반 $\alpha_{T o}-a_{i n t o 1}$ 와 차이를 보였다. 3-링크

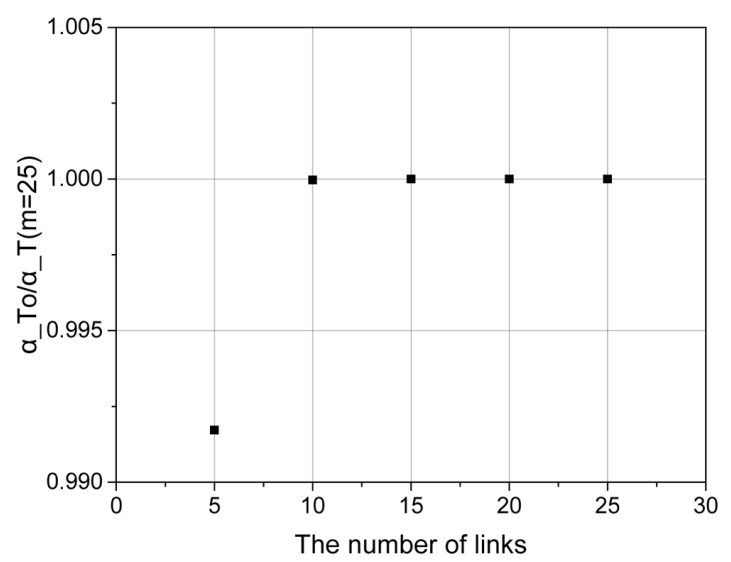

Fig. 16 Convergence test result for the number of links

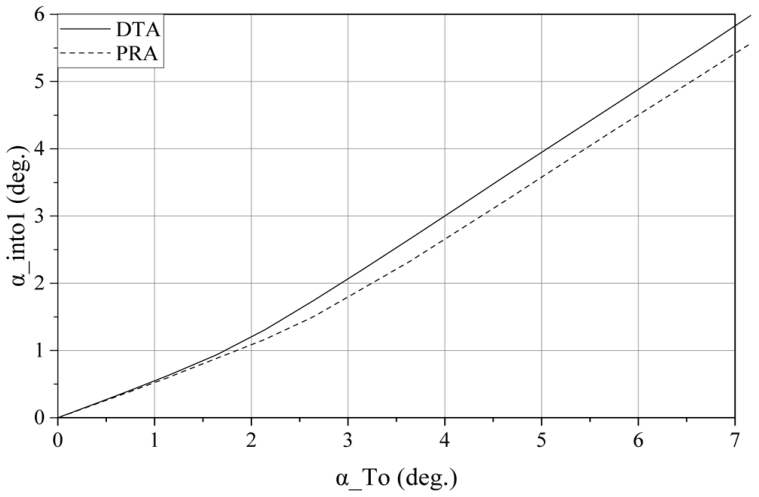

(b) $T=0.3 P_{m b l}$

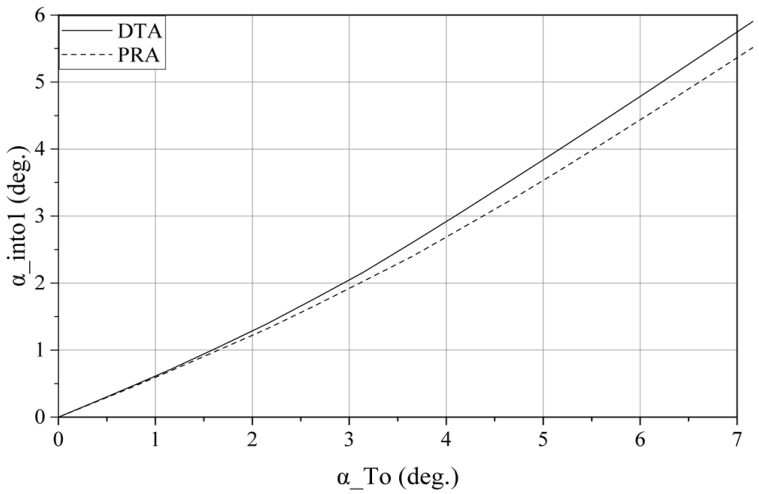

(c) $T=0.5 P_{m b l}$

Fig. 17 Relation of tension angle versus interlink angle 
해석법은 국부 응력 평가에도 영향을 미칠 뿐만 아니라, 다중링크 해석에도 영향을 미친다는 증거이다.

\section{4. 토 의}

$\mathrm{OPB}$ 를 고려한 누적 피로를 산정하기 위해서는 Fig. 4에 제시 된 절차를 따라야 한다. 즉 유체동역학 해석을 통하여 인장력의 이력과 인장각의 이력을 얻어야 한다. Fig. 18은 Fig. 9에 제시한 풍력 발전기의 시간 응답 해석을 통하여 얻은 1 번 계류선의 인 장력 이력과 인장각 이력을 나타낸다. 인장력의 평균값은 소위 초기 인장(Pre-tension)과 조류 등에 의하여 발생한 항력에 의한 인장력을 포함한다.

극한 하중의 관점에서 인장력의 평균값은 매우 중요하다. 반 면, 인장력-수명 선도 또는 응력-수명 선도는 응력 비 또는 하중 비가 0이 되도록 실험하여 얻은 것이므로, 평균 인장력 또는 평 균 응력의 효과가 이미 인장력-수명 선도 또는 응력-수명 선도 에 포함된 것으로 간주한다. 이러한 이유로 피로의 관점에서 인 장력의 범위만을 사용하며, Rainflow 집계법을 이용하여 인장력 의 범위를 집계할 수 있다.

Fig. 18 에 제시된 인장각은 부유체의 운동 이력과 인장력의 이력을 동시에 고려하여 생성되어야 한다. 즉 페어리드 또는 체 인 호스 등이 사용될 경우, 부유체의 운동을 고려한 $\mathrm{OPB}$ 인장 각의 평균값은 항상 0 을 가지도록 정규화되어야 한다. Fig. 18 에 제시된 인장각의 평균은 0 임을 직관적으로 알 수 있다.

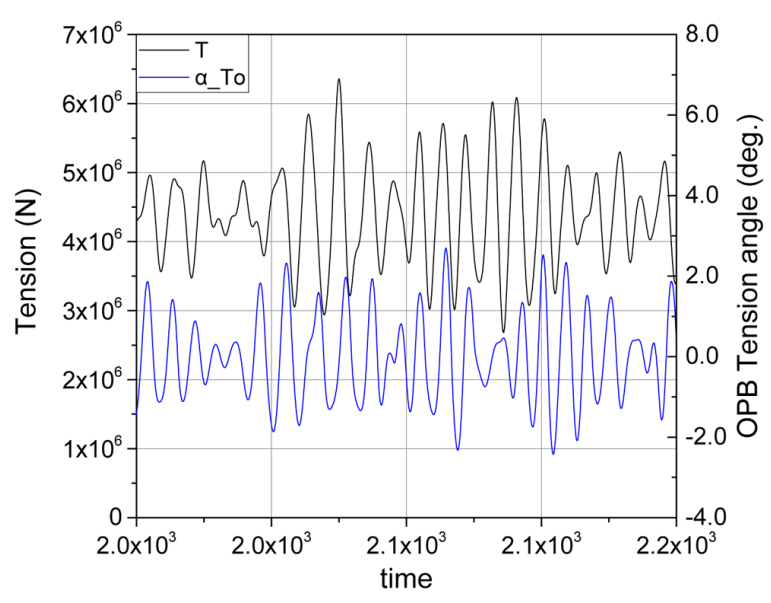

Fig. 18 Time processes of tension load and tension angle

\section{5. 결 론}

$\mathrm{OPB}$ 모멘트의 발생 기구를 설명하였으며, PRA와 DTA에 기 반한 3-링크 해석에 대하여 소개하였다. 또한 3-링크 해석 및 다 중-링크 해석을 고려한 $\mathrm{OPB}$ 피로 해석 절차에 대하여 소개하였 다. PRA와 DTA에 기반한 3-링크 해석의 차이점에 대하여 상세 한 소개를 하였다. 특히 $\mathrm{OPB}$ 모멘트의 분포를 비교하여(상기) 두 방법의 차이점을 확인하였다. 다중-링크 해석의 필요성에 대 하여 고찰하였다.

$8 \mathrm{MW}$ 급 부유식 해상 풍력 발전 플랫폼에 사용된 계류선을 벤 치마크 스터디 모델로 선택하였으며, 공칭 지름 $107 \mathrm{~mm}$, 소재
등급 $\mathrm{R} 4$ 를 가정하여 링크의 속성을 $\mathrm{DNV}$ 규정 $\mathrm{DNV}, 2010)$ 에 의거하여 제시하였다. 3-링크 해석 모델을 구성하는 과정과 이 에 적용된 하중 및 경계 조건에 대하여 제시하였다. PRA 기반 및 DTA 기반의 3-링크 해석 결과로서 응력의 분포를 비교하였 으며, 두 기법 간에 상당한 응력 분포의 차이가 있음을 확인하 였다. 또한 PRA 및 DTA에 기반한 3-링크 해석법과 BV 가이드 라인(BV, 2014)의 경험식에 의거하여 $\mathrm{OPB}$ 강성을 3 가지 인장력 수준별로 비교하였다. 3 가지 강성 추정 방법에 따라 $\mathrm{OPB}$ 강성 에 큰 차이가 있음을 확인하였다. 또한 PRA 및 DTA에 기반한 3-링크 해석법은 구속 모드에서 슬라이딩 모드로의 모드 천이 를 구분하기 어려웠다. 국부 응력을 3 가지 방법(PRA 및 DTA 기반의 3-링크 해석법과 $\mathrm{BV}$ 가이드라인)에 따라 비교한 결과, $\mathrm{BV}$ 가이드라인은 낮은 인장력에서 국부 응력을 과소 평가하고 높은 인장력에서 국부 응력을 과대 평가하는 것을 확인하였다. 3-링크 해석법은 인터링크 각의 증가에 따라 비선형 응력 집중 계수를 제시하였으나, BV 가이드라인은 비선형 응력 집중 계수 를 고려할 수 없었다. 또한 높은 인장력에서 급격한 국부 응력 의 감소로 인하여 응력 집중 계수도 매우 작아질 수 있음을 3링크 해석법으로부터 얻을 수 있었다.

링크의 최소 개수를 결정하기 위한 다중-링크의 수렴도 해석 을 통하여 10 개의 링크가 최소 개수임을 증명하였다. 또한 인장 각-인터링크 각의 관계를 10 개의 링크를 적용한 다중-링크 해석 을 통하여 도출한 결과 3-링크 해석에서 얻은 OPB 강성이 인장 각-인터링크 각의 관계에도 무시하지 못할 영향을 미친다는 사 실을 증명하였다.

시간 영역 유체동역학 해석을 통하여 얻은 인장력 이력과 인 장각 이력을 각각 예로 제시하였지만, 실제 하중 케이스를 고려 한 유체동역학 해석을 통한 실증이 요구된다. 또한 국부 응력 계 측이나 $\mathrm{OPB}$ 모멘트 계측 실험을 통하여 3-링크 해석법의 정확도 에 대하여 검증할 필요가 있다. 본 연구에서는 DTA가 PRA에 비 하여 좀더 사실에 근사하여 OPB 현상을 시뮬레이션할 수 있다 고 설명하였지만, 이에 대한 좀더 정량적인 근거가 요구된다.

\section{후 기}

이 논문은 2018년 해양수산부 재원으로 한국해양과학기술진흥 원의 지원을 받아 수행된 연구임(해양에너지 융복합 인력양성).

\section{References}

Bureau Veritas(BV), 2014. Fatigue of Top Chain of Mooring Lines due to In-plane and Out-of-plane Bendings: Guidance Note NI 604 DT R00E. BV, France.

Choung, J., Han, S., 2016a. A Novel Procedure for Mooring Chain Fatigue Prediction based on Maximum Principal Stress Considering Out-of-Plane and In-Plane Bending Effects. Journal of the Society of Naval Architects of Korea, 53(3), 237-248.

Choung, J., Han, S., 2016b. A Novel Approach to Predict Mooring Chain Fatigue Considering Out-of-Plane and In-Plane Bending Effects. Proceedings of 1st International Conference on Ships and Offshore Structures, Hamburg, Germany. 
Choung, J., Lee, J., 2018. Study on Prediction of Stresses by Out-of-Plane and In-Plane Bending Moments in Offshore Mooring Chain. Ships and Offshore Structures, 1-15.

Det Norske Veritas(DNV), 2010. Offshore Mooring Chain: Offshore Standard DNV-OS-E302. DNV, Norway.

Jean, P., Goessens, K., L'Hostis, D., 2005. Failure of Chains by Bending on Deepwater Mooring Systems. Proceedings of the Offshore Technology Conference, Houston Texas, USA.

Kim, M., Kim, Y., 2017. Nonlinear Finite Element Analysis for Mooring Chain Considering OPB/IPB. Journal of Ocean Engineering and Technology, 31(4), 299-307.

Li, C.B., Choung, J., Noh, M.H., 2018. Wide-banded Fatigue Damage Evaluation of Catenary Mooring Lines using Various Artificial Neural Networks models. Marine Structures, 60, 186-200.

Lim, Y., Kim, K., Choung, J., Kang. C., 2010. A Study on Out-of-Plane Bending Mechanism of Mooring Chains for Floating Offshore Plants. Journal of the Society of Naval Architects of Korea, 47(4), 580-588.

Melis, C., Jean, P., Vargas, P., 2005. Out-of-Plane Bending Testing of Chain Links. Proceedings of $24^{\text {th }}$ International Conference on Offshore Mechanics and Arctic Engineering, Halkidiki, Greece.
Rampi, L., Vargas, P., 2006. Fatigue Testing of Out-of-Plane Bending Mechanism of Chain Links. Proceedings of $25^{\text {th }}$ International Conference on Offshore Mechanics and Arctic Engineering, Hamburg, Germany.

Lee, J.B., Koo, W., Choung, J., 2018, Out-of-Plane Bending MomentInduced Hotspot Stress Evaluation Using Advanced Numerical Technique. Proceedings of the $37^{\text {th }}$ International Conference on Offshore Mechanics and Arctic Engineering, Madrid, Spain.

Rampi, L., Dewi, F., Vargas, P., 2015. Chain Out of Plane Bending(OPB) Joint Industry Project(JIP) Summary and Main Results. Proceedings of the Offshore Technology Conference, Houston Texas, USA.

Rampi, L., Dewi, F., Francois, M., Gerthoffert, A., Vargas, P., 2016a. Chain out of Plane Bending(OPB) Fatigue Joint Industry Project(JIP) Static Test Program and OPB Interlink Stiffness. Proceedings of the $35^{\text {th }}$ International Conference on Offshore Mechanics and Arctic Engineering, Busan, South Korea.

Rampi, L., Bignonnet, A., Cunff, C.L., Bourgin, F., Vargas, P., 2016b. Chain out of Plane Bending(OPB) Fatigue Joint Industry Project(JIP) Fatigue Test Program Results and Methodology. Proceedings of the $35^{\text {th }}$ International Conference on Offshore Mechanics and Arctic Engineering, Busan, South Korea. 